\section{Questions for our fairy godmother}

\section{Why Aren't Black Holes Black? The Unanswered Questions at the Frontiers of Science}

by Robert M. Hazen and Maxine Singer Anchor: 1997. Pp. 309. \$12.95

\section{Lewis Wolpert}

Being a scientist gives Stephen Jay Gould a continuing sense of privilege and reward. Science is for him the best technique we have for gaining knowledge about the world. $\mathrm{He}$ sees relativism - the argument that science is merely a social construct - as "perniciously wrongheaded", and dismisses claims that science is finished as being astonishingly superficial. We remain ignorant about many of the deepest questions, and this is precisely what this book - which contains an introduction by Gould - aims to illuminate.

Robert M. Hazen and Maxine Singer try to examine the limits to which we have probed the physical and biological world. This is a grand ambition and the result is a mixed success. Starting with an analysis of the nature of scientific questions, they recognize that some questions are more fundamental than others. Peter Medawar coined a profound aphorism when he spoke of science as being the art of the soluble. Asking the right questions is at the very heart of great science and is probably more difficult than actually solving them. I fantasize about Goofgoos, the Good Fairy Godmother of Science, to whom one could put just one question. Every scientist should know exactly what question they would ask, noting that only a very brief answer will be given. It was just such questions that I hoped this book would spell out. But much of the book is instead a well-written popular review of

\section{New in paperback}

\section{Blondes in Venetian Paintings, the Nine-Banded Armadillo, and Other Essays in Biochemistry}

by Konrad Bloch

Yale University Press, $\$ 16, £ 11$

"The author displays a wide appreciation of metabolism, nutrition and comparative biology. The essays vary greatly in originality and new insights, although they all have something of interest for a diverse readership", wrote Wilfred Niels Arnold in Nature 374, 130 (1995).

\section{Driving Force: The Natural Magic of Magnets}

by James D. Livingston

Harvard University Press, \$14.95, £9.95

"A smashing book.... In an era of the whole of science - well, nearly all, because psychology, economics and sociology are absent.

The authors start with cosmology, the age and future of the Universe and why the Universe is lumpy, but also ask some questions that seem just outside science, such as whether life has meaning. They ask where are the WIMPs, the weakly interacting massive particles, that might provide the answer to all that embarrassing missing dark matter - 99 per cent of the Universe is just nowhere to be seen. Goofgoos, help please. She could also help with the Theory of Everything. But here there remains a problem that the authors do not explore. For, even if a cohesive set of equations is discovered from which everything else can be derived, we will still always beleft with that seemingly unanswered question as to what explains that theory.

When discussing chemistry in terms of how atoms combine, Hazen and Singer suggest that, while molecules provide the basis of life, it may never be possible to predict the behaviour of living things from fundamental principles alone. This is an important question which relates to a reductionist issue that pervades the whole book. What do we regard as a satisfactory explanation for any set of phenomena? Biology has been brilliantly successful in explaining cell behaviour and inheritance in molecular terms, but is going down to the next level necessary or even interesting? Do we have to know the fundamental chemistry of enzyme action to explain metabolism or DNA replication?

Nowhere is this more evident than in relation to human and animal behaviour. In what terms are we to explain them? What would we regard, for example, as a satisfactory account of love or depression? It is easier to think about the physical basis of memory in terms of the synapses and molecular changes that the authors discuss, but we still have a very long way to go.

unfortunate public distrust and misunderstanding of the scientific method, I wish there were more science books for the general population written with so engaging an approach", wrote Paul M. Grant in Nature 380, 679 (1996).

The Challenger Launch Decision: Risky Technology, Culture, and Deviance at NASA

by Diane Vaughan

University of Chicago Press, $\$ 14.95$

"[Vaughan] has delved deep into the archives and conducted interviews with many of the protagonists", wrote Harry Collins in Nature 380, 297 (1996).
Topics covered include the quest for energy, population growth, the origins of the Earth and life itself. It is a fun if occasionally irritating book to read; the authors have, for example, no real insight into my own subject, developmental biology, and their evolutionary biology is weakish. There are also repeated references to the so-called ethical issues raised by science. But I learned a great deal about topics such as the inner structure of the Earth and the serious attempts to find life elsewhere in the Universe. The book gives in an accessible form a nice feel of what science is about.

Lewis Wolpert is in the Department of Anatomy, University College London, Medawar Building, Gower Street, London WCIE 6BT, UK.

\section{The chemist as accountant}

\section{Lavoisier: Chemist, Biologist, Economist}

by Jean-Pierre Poirier

University of Pennsylvania Press: 1997.

Pp. 516. \$49.95, 247.50

Maurice Crosland

The work of Antoine Lavoisier (17431794) marked a turning point in the history of chemistry. Following the 'chemical revolution' of the late eighteenth century, of which he was the central figure, chemistry emerged almost as a new science. Indeed, it became the model science at a time when physics still lacked unity and coherence. Lavoisier not only reordered much of the science around oxygen, he also drew up a list of elements as the building blocks of inorganic chemistry. Only on the basis of these elements was it possible a generation later for John Dalton to introduce his atomic theory.

It would be difficult for a modern scientist to understand a chemistry book written before the time of Lavoisier, since in 1787 the leading French chemists collaborated to replace the previously chaotic nomenclature by a simple rational system, in which the names of compounds reflected their constituents.

Most readers would therefore expect a book on Lavoisier to be about his chemistry. Although Jean-Pierre Poirier tells the chemical story, he also tells much more, since his original interest lay in the financial and economic aspects of Lavoisier's life. For Lavoisier was very much more than a chemist.

One must not fall into the trap of supposing that all chemists started with a scientific education and then used their chemical expertise as the basis of their livelihoods. Lavoisier was educated in the classics, followed by a degree in law. He did, however, attend one course of chemistry 